\title{
Impact of USA Oil and Natural Gas Emission Increases on Surface Ozone is most pronounced in the Central U.S.
}

\author{
Andrea Pozzer ${ }^{1, *}$, Martin G. Schultz ${ }^{2}$, and Detlev Helmig ${ }^{3, a}$
}

\author{
${ }^{1}$ Max Planck Institute for Chemistry, Hahn-Meitner-Weg 1, 55128 Mainz, Germany \\ ${ }^{2}$ Jülich Supercomputing Centre, Forschungszentrum Jülich GmbH, Wilhelm-Johnen-Str., 52425 Jülich, Germany \\ ${ }^{3}$ Boulder A.I.R. LLC, Boulder, Colorado 80305, United States \\ a now at: Boulder A.I.R. LLC, Boulder, Colorado 80303, United States \\ *Corresponding author: andrea.pozzer@mpic.de
}

\section{Supporting Information}

April 20, 2020

\author{
Number of Pages: 14 \\ Number of Figures: 8 \\ Number of Tables: 2
}

SI_Table 1. List of sites, sorted by latitude, within the GGGRN that provided VOC data that were used for deriving ethane global inventory estimate adjustments. (Page S3)

SI_Table 2. Growth rate of atmospheric ethane from FTIR tropospheric column measurements. (Page S4)

SI_Figure 1: Oil and natural gas production trends in the U.S. Oil data are from https://www.eia.gov/dnav/pet/pet_crd_crpdn_adc_mbbl_m.htm; natural gas data are from https://www.eia.gov/dnav/ng/hist/n9010us2m.htm. (Page S5)

SI_Figure 2: Comparison of Global Greenhouse Gas Reference Network observations (circles) with the Model_Run_O\&NG_Trend simulation results (red line). Monthly mean data are shown for the observations, with error bars indicating the $1-\sigma$ variability of monthly data (both for model and observations). Please see SI_Table 1 for site names and locations corresponding to the three-letter code. Graphs are arranged in order of decreasing site latitude. (Page S6-S8)

SI_Figure 3: Comparison of GGGRN ethane trends seen in the observations with the Model_Run_O\&NG_Trend model output. Data points are color coded by the site latitude according to the scale provided to the right, and labeled by the three-letter site code (SM_Table 2). (Page S9)

SI_Figure 4: Year 2009-2014 surface ozone trends at TOAR sites. The arrow slopes corresponds to the trend magnitude, according to the scale in the lower right of the graph, and arrow colors indicate the p-values of a Sen-Theil test of the significance of the trend slope results, as indicated in the legend. (Page S10)

SI_Figure 5: (a) 2009 to 2014 mean summer ozone changes for North America and bordering oceans 
from the model run Model_Run_Constant, where emissions where frozen to 2009 levels. Ozone changes in this analysis primarily reflect meteorological influences over this time window. (b) Results from the Model_Run_O\&NG_Trend. (Page S11)

SI_Figure 6: Ozone output from the model for a midwestern U.S. location $\left(100^{\circ} \mathrm{W}, 40^{\circ} \mathrm{N}\right)$ (Model_Run_O\&NG_Trend) with fitting results for year-to-year changes (green) and linear trend (red) fit through the 2009-2014 data. (Page S12)

SI_Figure 7: Enlargements of results shown in Figure 3 of the main paper, showing additional days with 8-hour ozone $>70 \mathrm{ppb}$ for the Central US and California from the O\&NG emissions growth from 2009 to 2014. (Page S12)

SI_Figure 8: U.S. map showing counties that as of September 2018 were in non-attainment of the 2015 ozone NAAQS (https://www3.epa.gov/airquality/greenbook/map8hr_2015.html). (Page S13)

SI_Text 1: Mortality estimate (Page S13) 
SI_Table 1. List of sites, sorted by latitude, within the NOAA Global Greenhouse Gases Reference Network (GGGRN) that provided VOC data that were used for deriving ethane global inventory estimate adjustments.

\begin{tabular}{|c|c|c|c|c|}
\hline Site Code & Name & Country & Lat & Long \\
\hline ALT & Alert, Nunavut & Canada & 82.5 & -62.5 \\
\hline ZEP & Ny-Alesund, Svalbard & Norway/Sweden & 78.9 & 11.9 \\
\hline SUM & Summit & Greenland & 72.6 & -38.5 \\
\hline TIK & Tiksi & Russia & 71.6 & 128.9 \\
\hline BRW & Barrow, Alaska & United States & 71.3 & -156.6 \\
\hline PAL & Pallas-Sammaltunturi & Finland & 68.0 & 24.1 \\
\hline ICE & Storhofdi, Vestmannaeyjar & Iceland & 63.3 & -20.3 \\
\hline BAL & Baltic Sea & Poland & 55.4 & 17.2 \\
\hline CBA & Cold Bay, Alaska & United States & 55.2 & -162.7 \\
\hline LLB & Lac La Biche, Alberta & Canada & 55.0 & -112.5 \\
\hline MHD & Mace Head, County Galway & Ireland & 53.3 & -9.9 \\
\hline SHM & Shemya Island, Alaska & United States & 52.7 & 174.1 \\
\hline OXK & Ochsenkopf & Germany & 50.0 & 11.8 \\
\hline HPB & Hohenpeissenberg & Germany & 47.8 & 11.0 \\
\hline LEF & Park Falls, Wisconsin & United States & 45.9 & -90.3 \\
\hline AMT & Argyle, Maine & United States & 45.0 & -68.7 \\
\hline BSC & Black Sea, Constanta & Romania & 44.2 & 28.7 \\
\hline THD & Trinidad Head, California & United States & 41.1 & -124.2 \\
\hline UTA & Wendover, Utah & United States & 39.9 & -113.7 \\
\hline AZR & Terceira Island, Azores & Portugal & 38.8 & -27.4 \\
\hline SGP & Southern Great Plains, Oklahoma & United States & 36.8 & -97.5 \\
\hline TAP & Tae-ahn Peninsula & Korea & 36.7 & 126.1 \\
\hline BMW & Tudor Hill & Bermuda & 32.3 & -64.9 \\
\hline IZO & Tenerife, Canary Islands & Spain & 28.3 & -16.5 \\
\hline MID & Sand Island, Midway & United States & 28.2 & -177.4 \\
\hline KEY & Key Biscayne, Florida & United States & 25.7 & -80.2 \\
\hline ASK & Assekrem & Algeria & 23.2 & 5.4 \\
\hline KUM & Cape Kumakahi, Hawaii & United States & 19.5 & -154.8 \\
\hline MLO & Mauna Loa, Hawaii & United States & 19.5 & -155.6 \\
\hline MEX & High Alt. Global Climate Obs. Ctr. & Mexico & 19.0 & -97.3 \\
\hline GMI & Mariana Islands & Guam & 13.4 & 144.8 \\
\hline MKN & Mount Kenya & Kenya & -0.1 & 37.3 \\
\hline BKT & Bukit Kototabang & Indonesia & -0.2 & 100.3 \\
\hline SEY & Mahe Island & Seychelles & -4.7 & 55.2 \\
\hline NAT & Maxaranguape & Brazil & -5.5 & -35.3 \\
\hline ASC & Ascension Island & United Kingdom & -7.9 & -14.4 \\
\hline SMO & Tutulia & American Samoa & -14.2 & -170.6 \\
\hline EIC & Easter Island & Chile & -27.2 & -109.5 \\
\hline CGO & Cape Grim, Tasmania & Australia & -40.7 & 144.7 \\
\hline CRZ & Crozet Island & France & -46.5 & 51.9 \\
\hline USH & Tierra Del Fuego, Ushuaia & Argentina & -54.9 & -68.5 \\
\hline PSA & Palmer Station & Antartica & -64.9 & -64.0 \\
\hline SYO & Syowa Station & Antartica & -69.0 & 39.6 \\
\hline HBA & Hailey Station & UK & -75.6 & -26.2 \\
\hline SPO & South Pole & Antartica & -90.0 & -24.8 \\
\hline
\end{tabular}


SI_Table 2. Growth rate of atmospheric ethane from Fourier-transform infrared spectroscopy (FTIR) tropospheric column measurements.

\begin{tabular}{|l|l|c|c|c|}
\hline Study & Site & Site Latitude & Time Period & Rate of Change \\
\hline & & $\mathbf{0}^{\mathbf{0}}$ & & . \\
\hline Hausmann et al., 2014 & Zugspitze & 47.4 & $2007-2014$ & 3.2 \\
\hline Franco et al., 2015 & Jungfraujoch & 46.5 & $2009-2014$ & $4.90 \pm 0.91$ \\
\hline Franco et al., 2016 & Eureka & 80 & $2009-2014$ & 3.5 \\
\hline & Thule & 77.5 & $2009-2014$ & 3.2 \\
\hline & Jungfraujoch & 46.5 & $2009-2014$ & 4.9 \\
\hline & Toronto & 43.7 & $2009-2014$ & 5.4 \\
\hline & Boulder & 40 & $2009-2014$ & 5.1 \\
\hline Helmig et al., 2016 & Mauna Loa & 19.5 & $2009-2014$ & 3.0 \\
\hline & Jungfraujoch & 46.5 & $2009.5-2015.5$ & $4.2 \pm 1.0$ \\
\hline & Jungfraujoch & 46.5 & $2009.5-2015.5$ & $6.0 \pm 1.1$ \\
\hline & & & mean: & 4.3 \\
\hline a & & & median: & 4.6 \\
\hline bid-troposphere & & & & \\
\hline & & & & \\
\hline
\end{tabular}




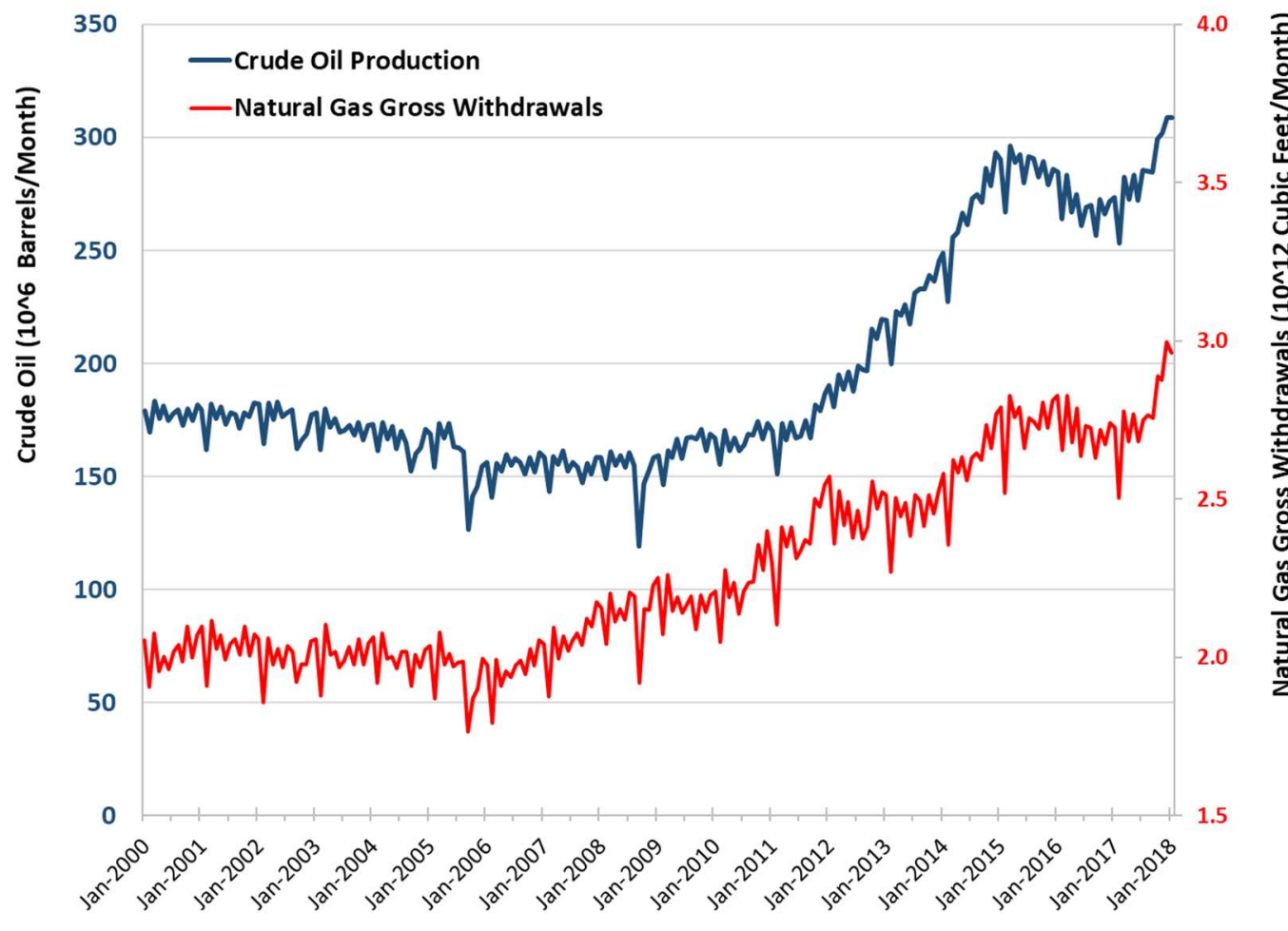

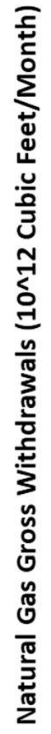

SI_Figure 1: Oil and natural gas production trends in the U.S. Oil data are from https://www.eia.gov/dnav/pet/pet_crd_crpdn_adc_mbbl_m.htm; natural gas data are from https://www.eia.gov/dnav/ng/hist/n9010us2 m.htm. 

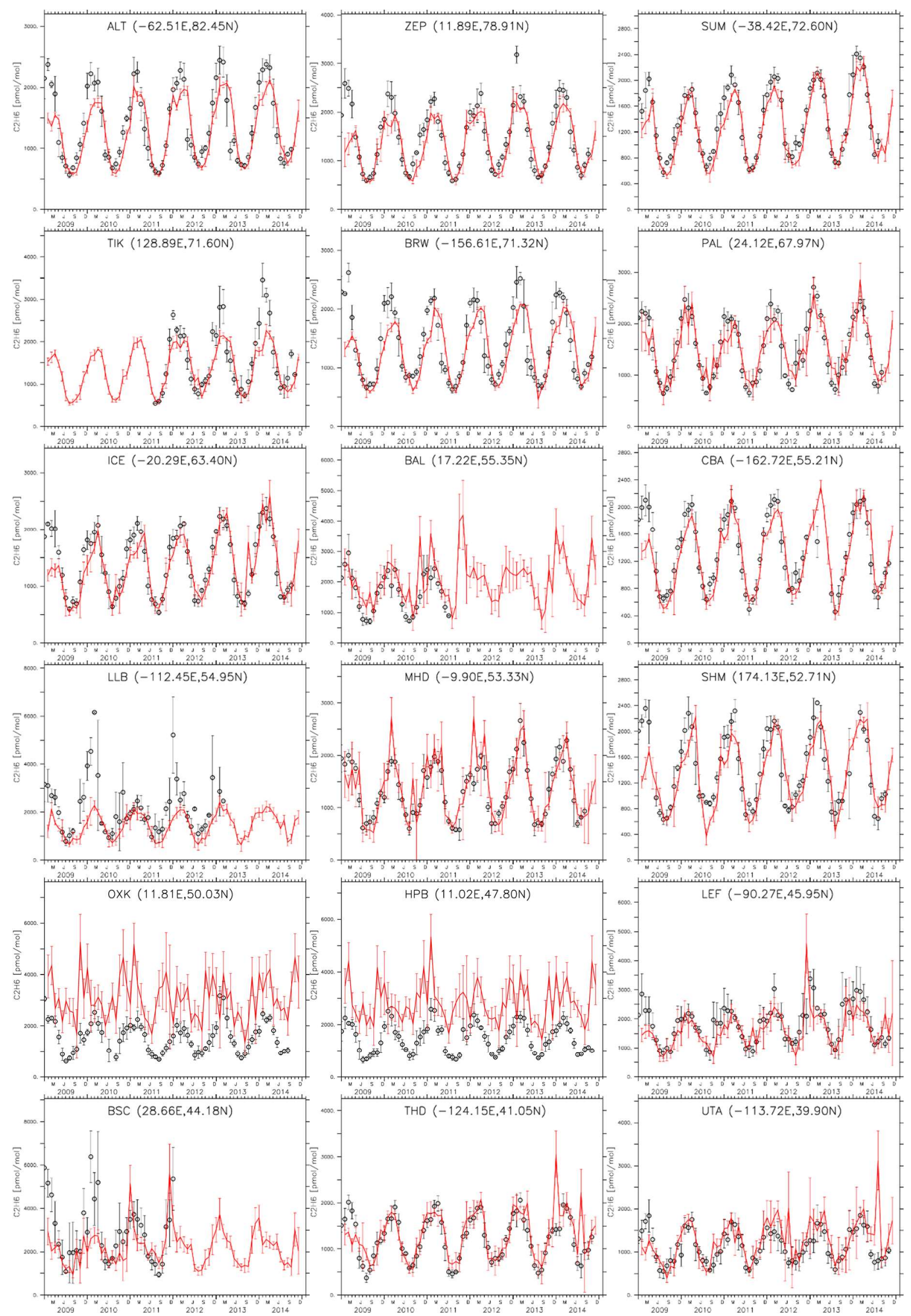

SI_Figure 2: Comparison of Global Greenhouse Gas Reference Network observations (circles) with the Model Run O\&NG Trend simulation results (red line). Monthly mean data are shown for the observations, with error bars indicating the 1- $\sigma$ variability of monthly data (both for model and observations). Please see SI Table 1 for site names and locations corresponding to the three-letter code. Graphs are arranged in order of decreasing site latitude. 


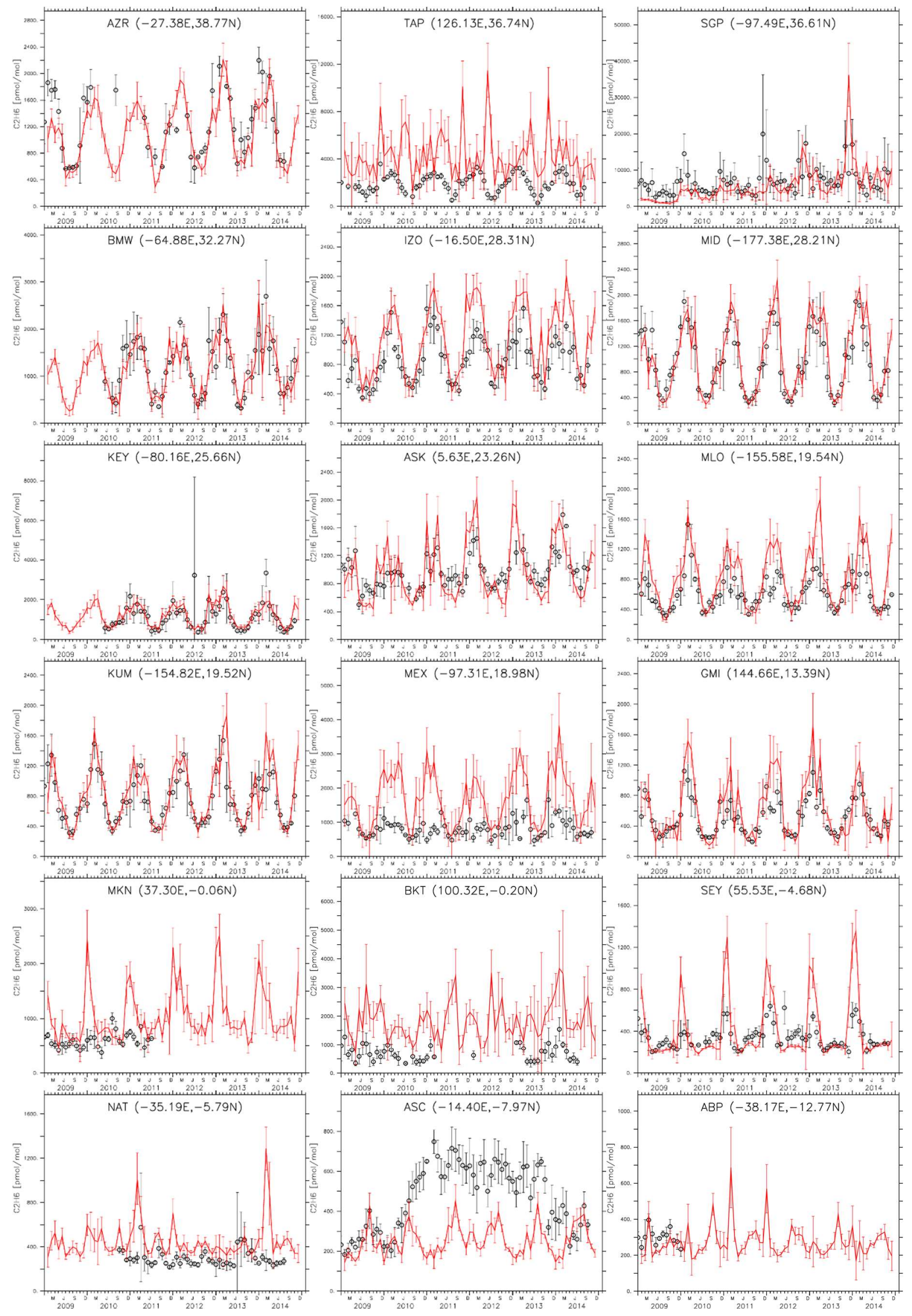

SI_Figure 2 (continued) 


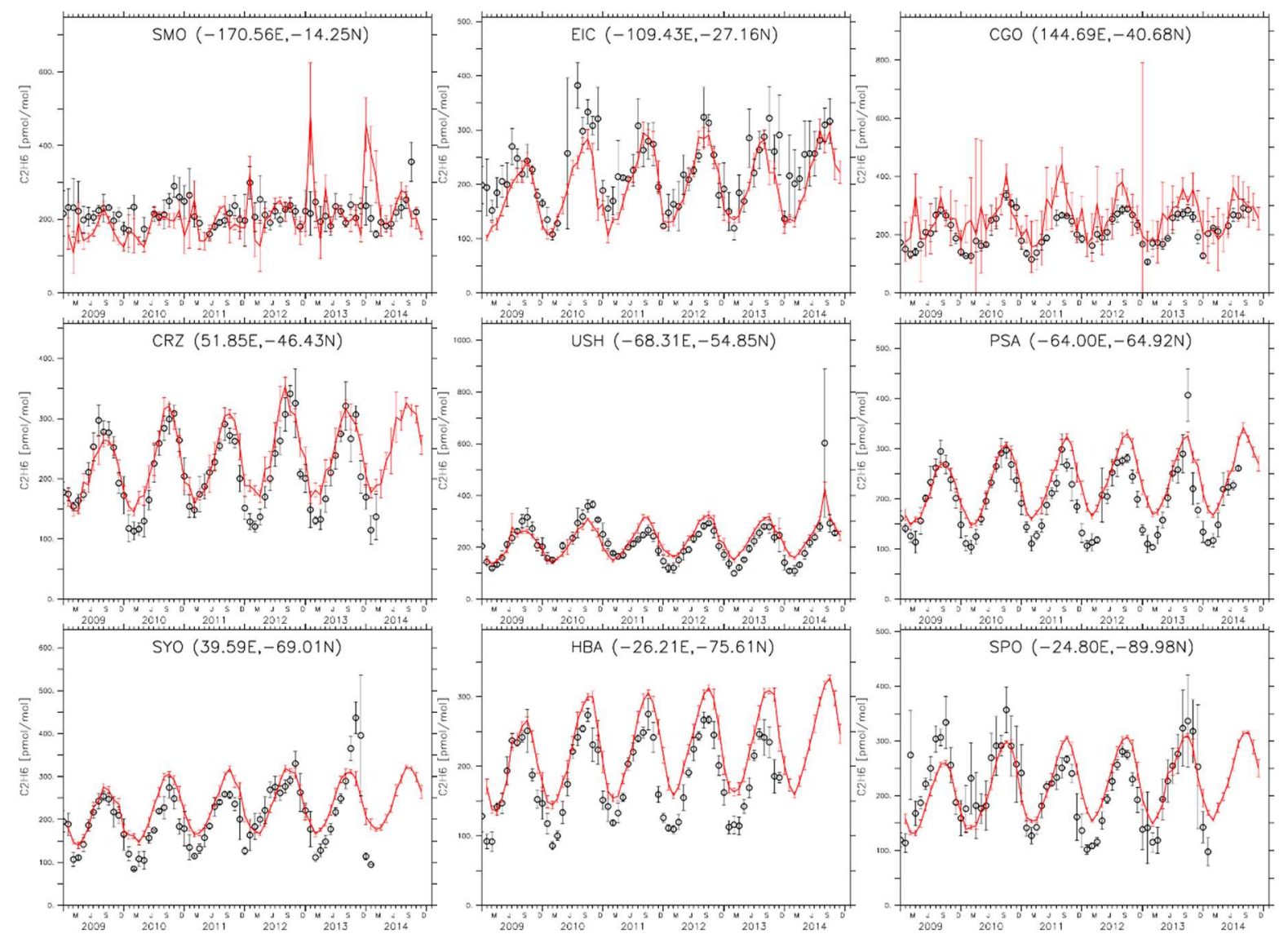

SI_Figure 2 (continued) 

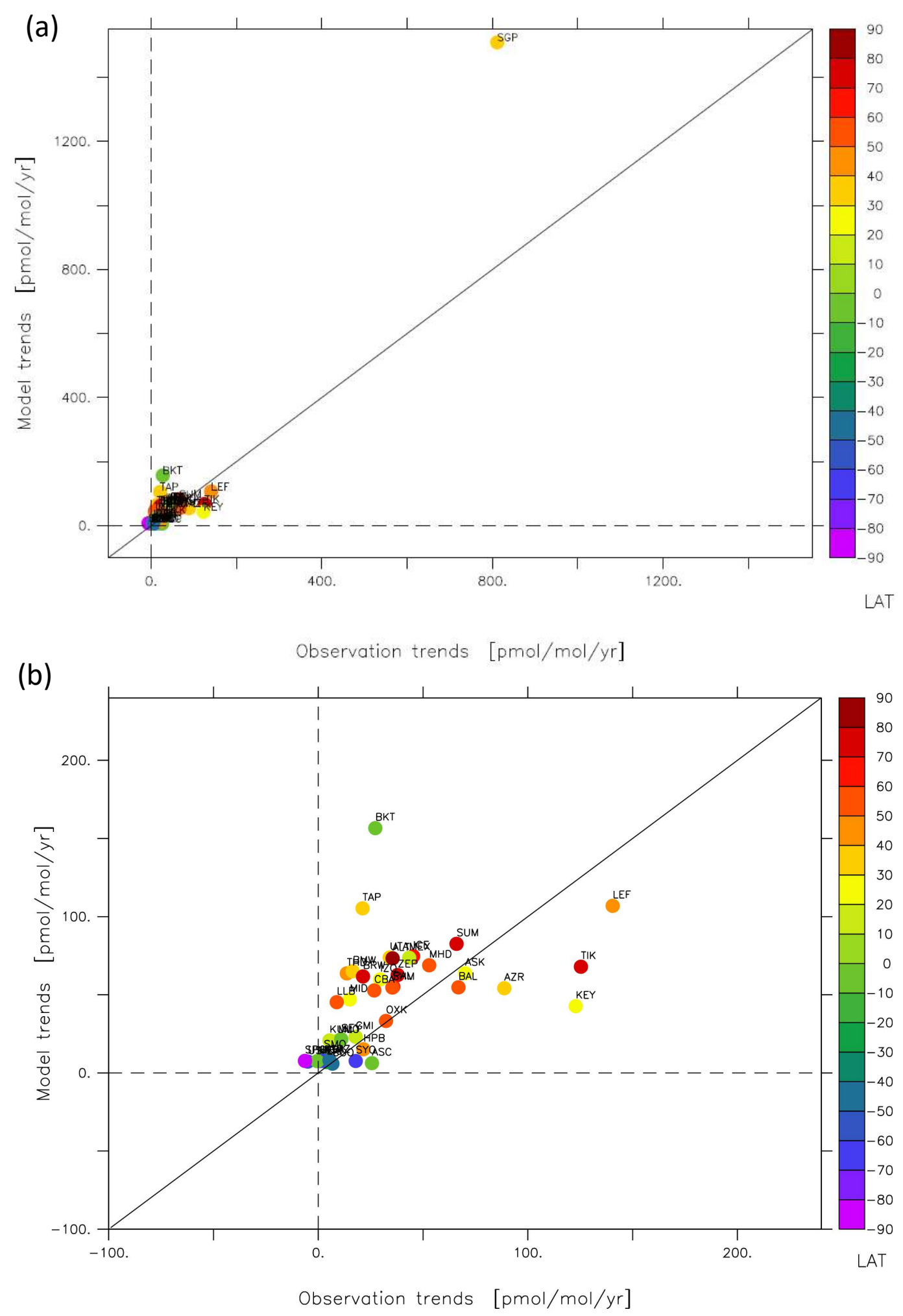

SI_Figure 3: Comparison of ethane trends seen in the observations with the Model_Run_O\&NG_Trend model output. Data points are color coded by the site latitude according to the scale provided to the right, and labeled by the three-letter site code (SM_Table 2). (a) All data; (b) enlargement of the $0-200 \mathrm{pmol} / \mathrm{mol} / \mathrm{yr}$ chart area. 


\section{Sen-Theil trend estimate of mean summer2009-2014, All stations}

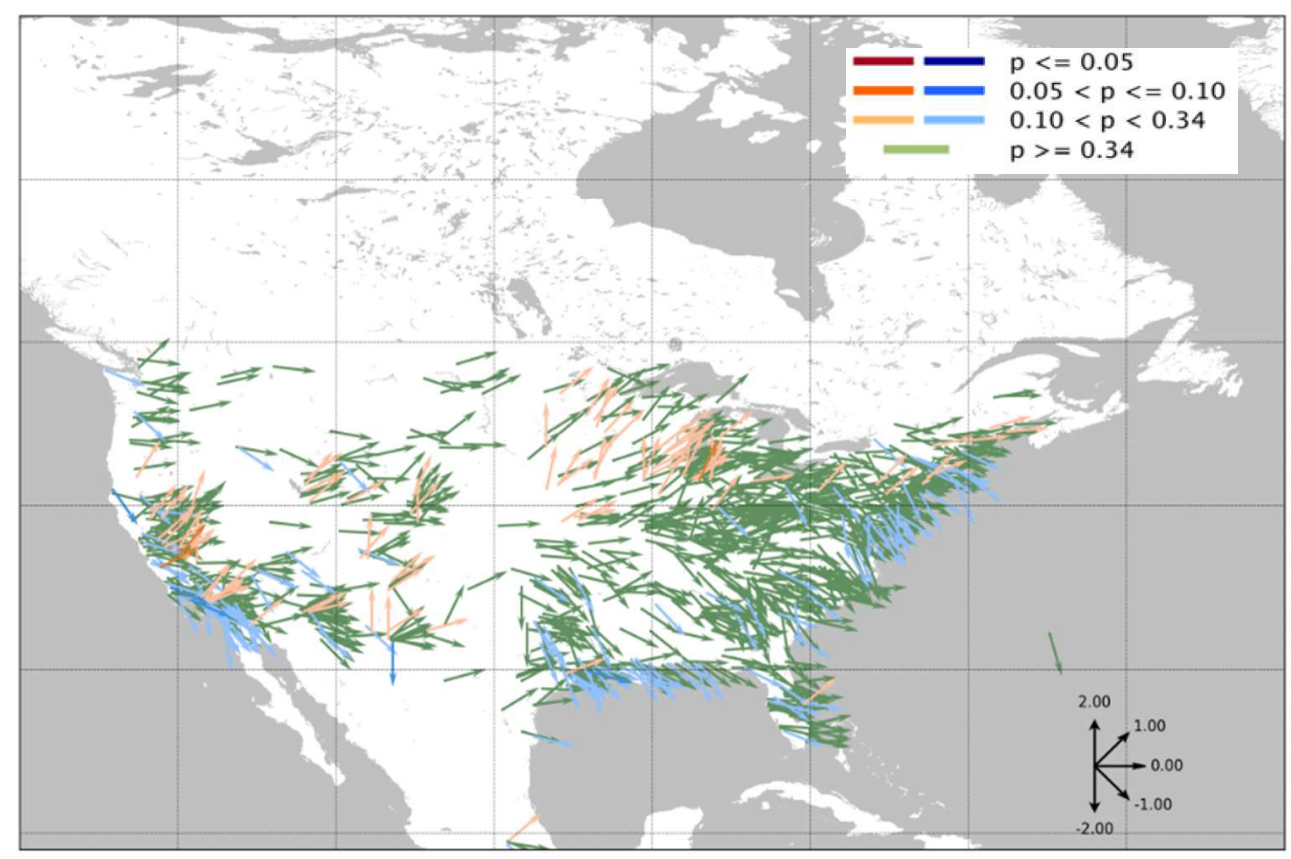

SI_Figure 4: Year 2009-2014 surface ozone trends at sites included in the Tropospheric Ozone Assessment Report (TOAR) ${ }^{1}$. The arrow slopes corresponds to the trend magnitude, according to the scale in the lower right of the graph, and arrow colors indicate the p-values of a Sen-Theil test of the significance of the trend slope results, as indicated in the legend. 
(a)

\section{Modeled changes of summer average ozone (2014-2009)}

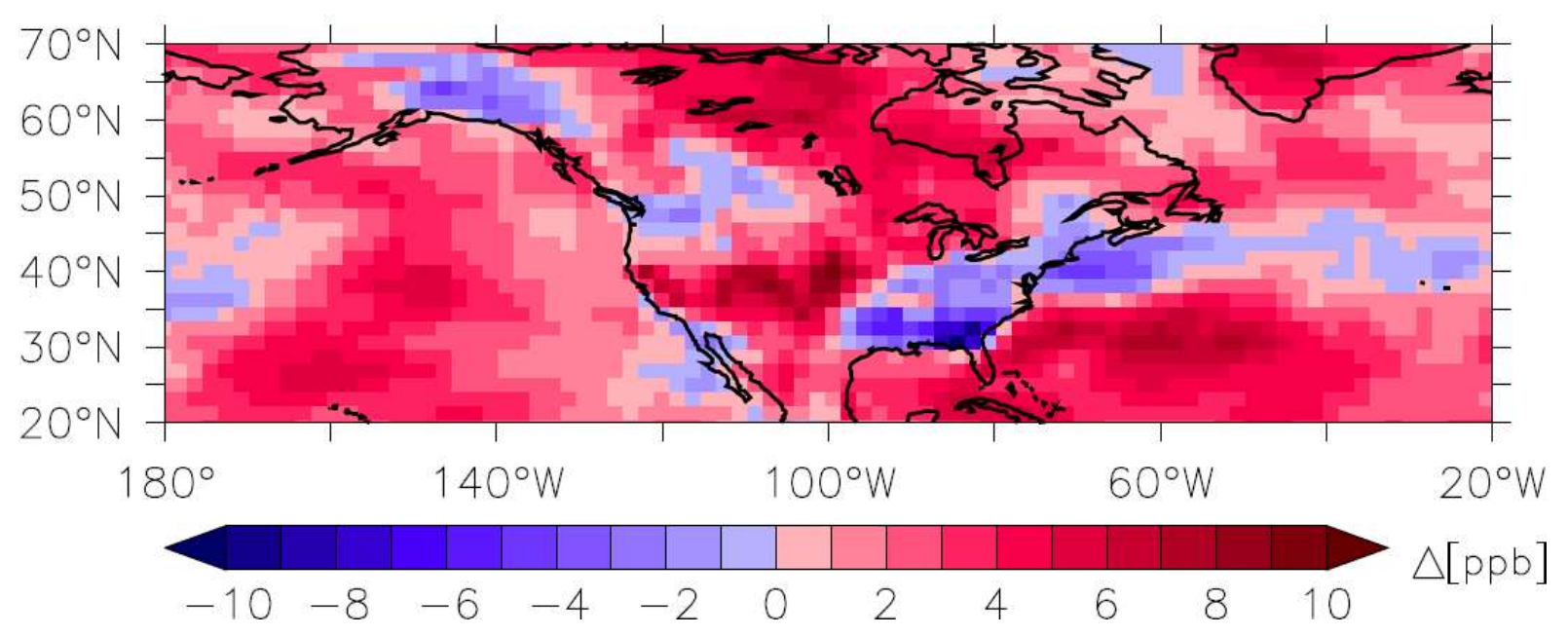

(b) Modeled changes of summer average ozone (2014-2009)

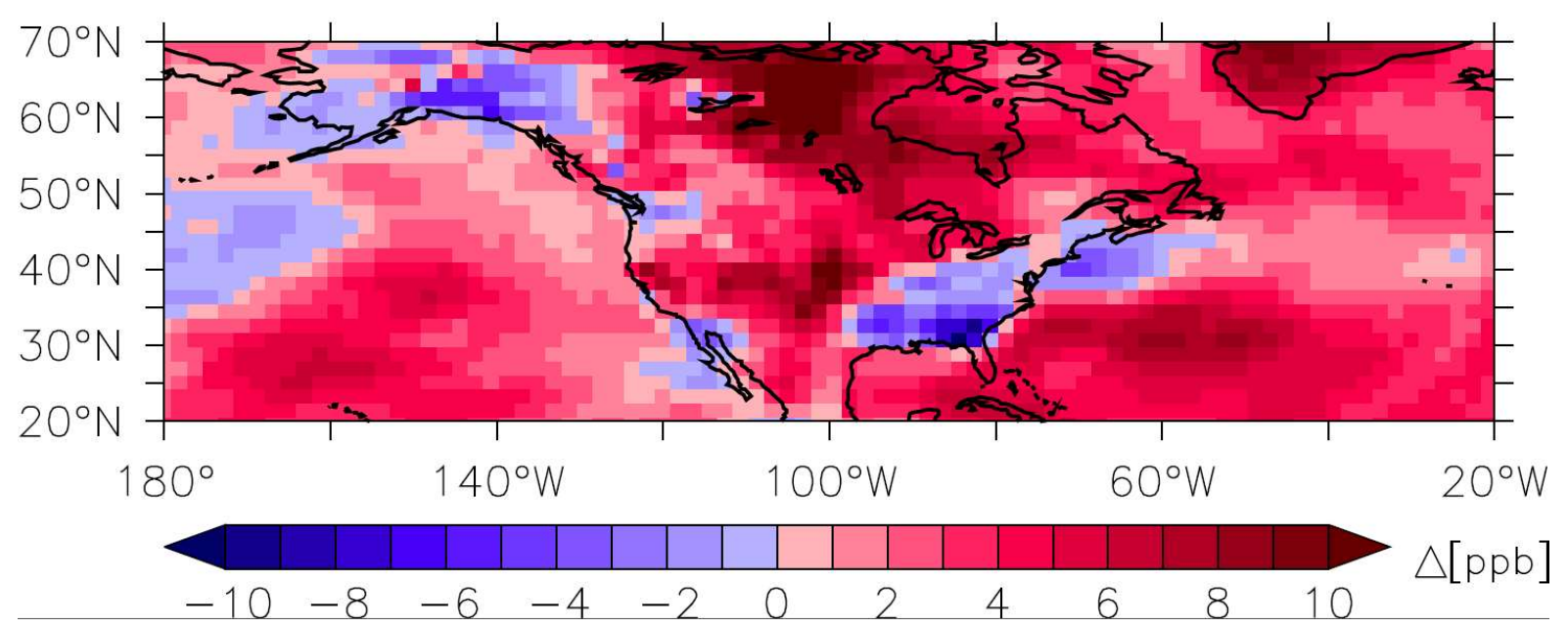

SI_Figure 5: (a) 2009 to 2014 mean summer ozone changes for North America and bordering oceans from the model run Model_Run_Constant, where emissions where frozen to 2009 levels. Ozone changes in this analysis primarily reflect meteorological influences over this time window. (b) Results from the Model_Run_O\&NG_Trend. 


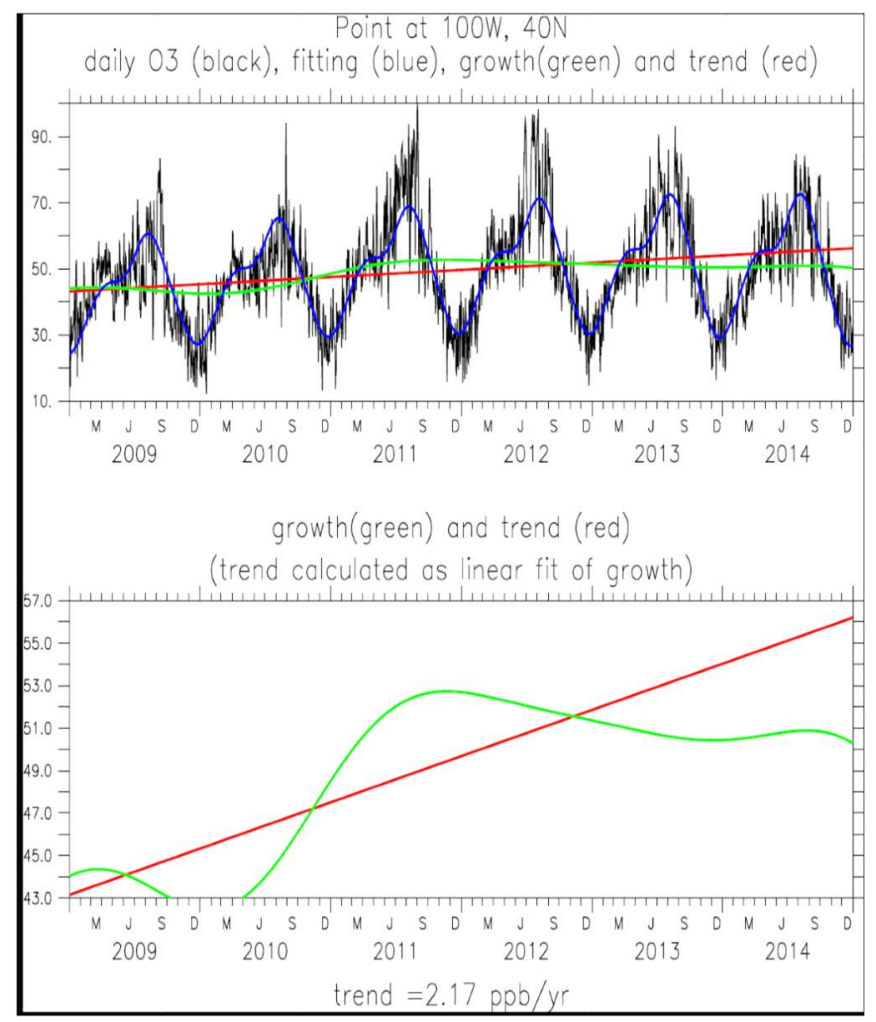

SI_Figure 6: Ozone output from the model for a midwestern U.S. location $\left(100^{\circ} \mathrm{W}, 40^{\circ} \mathrm{N}\right)($ Model Run $O \& N G$ Trend) with fitting results for year-toyear changes (green) and linear trend (red) fit through the 2009-2014 data.

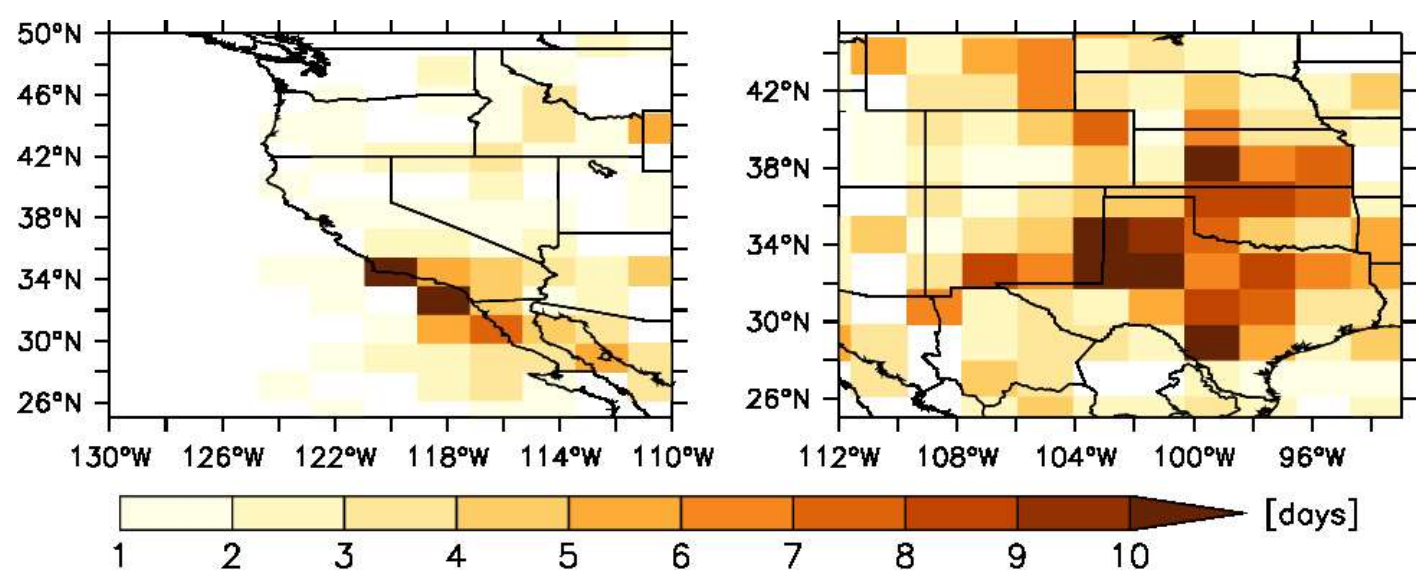

SI_Figure 7: Enlargements of results shown in Figure 3 of the main paper, showing additional days with 8-hour ozone $>70 \mathrm{ppb}$ for the Central US and California from the O\&NG emissions growth from 2009 to 2014. 


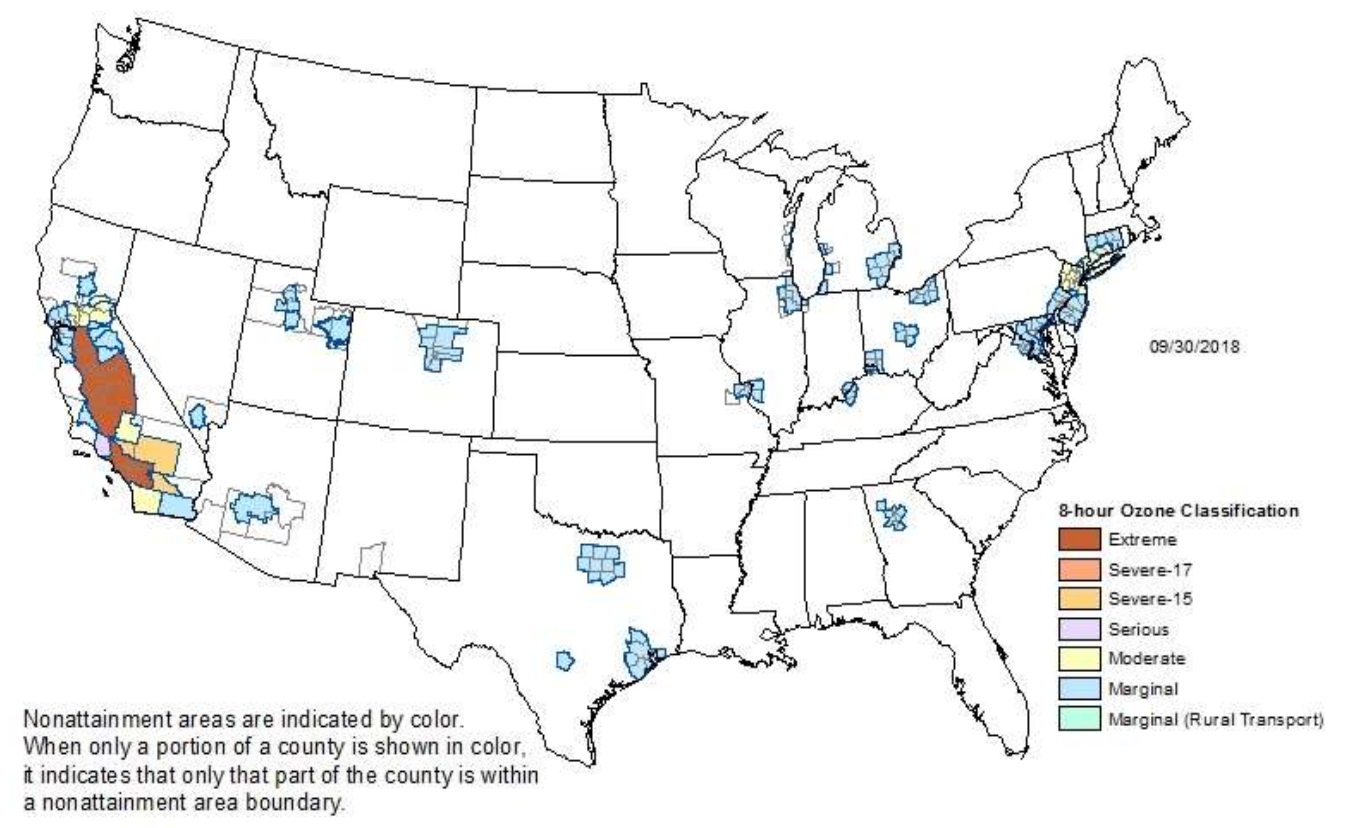

SI_Figure 8: U.S. map showing counties that as of September 2018 were in non-attainment of the 2015 ozone NAAQS (https://www3.epa.gov/airquality/greenbook/map8hr_2015.html).

\section{$\underline{\text { SI Text } 1}$}

Following a reviewer's suggestion, we conducted a preliminary assessment of the health effects from the oil and gas - produced ozone. We estimated mortality associated with long exposure to elevated ozone levels, which is linked to increased chronic obstructive pulmonary disease (COPD). The model was based on the exposure-response function from ${ }^{2}$, using updated coefficient, as presented by ${ }^{3}$, and followed the methodology described in ${ }^{4}$ and ${ }^{5}$. The population data for the USA were from the NASA Socioeconomic Data and Applications Center (SEDAC), hosted by the Columbia University Center for International Earth Science Information Network (CIESIN), available at a resolution of $2.5^{\prime} \times 2.5^{\prime}$ (about $5 \mathrm{~km} \times 5 \mathrm{~km}$ ) (http://sedac.ciesin.columbia.edu/). The total U.S. COPD mortality was obtained from the Global Burden of Disease (GBD) database for the year 2014 (http://www.healthdata.org/ gbd). Based on these input data and modeling, we estimated that on average approximately 12308 (11208-13208 with a CL of 95\%) people died prematurely in 2014 due to ozone pollution. This number is reduced to 12099 (10977-13021 with a CL of 95\%) in a model run that excludes the added oil and gas emissions and the additional ozone formed from these emissions. Consequently, this calculation estimates that the ozone that is produced from the added oil and gas emissions is responsible for an additional $\sim 320$ premature deaths per year. This number is lower than the 970 (range 520-1400) premature deaths from the total oil and gasproduced ozone that were projected for 2025 for the U.S. by Fann et al. [2018]. At least part of this difference can likely be explained by the time difference of these studies, i.e. the 11 years of continued growth of the O\&NG industry and associated emissions that were considered by Fann et al. [2018]. Further, our estimate has a relatively high uncertainty for numerous reasons, including the coarse resolution of the ECHAM model. There will be areas within 
each grid where the produced ozone is higher than the value calculated for the grid cell on average, and there will be areas where ozone will be lower. Given the non-linearity of the mortality-ozone relationship, it is more likely that our estimate is an underestimate rather than a high estimate. Please also note that this mortality estimate does not include possible reductions in mortality from the decreased emissions that result from the transition of coal to natural gas powered electricity generating plants.

\section{Supporting Information References}

1. Schultz, M. G.; Schroder, S.; Lyapina, O.; Cooper, O. R.; Galbally, I.; Petropavlovskikh, I.; von Schneidemesser, E.; Tanimoto, H.; Elshorbany, Y.; Naja, M.; Seguel, R. J.; Dauert, U.; Eckhardt, P.; Feigenspan, S.; Fiebig, M.; Hjellbrekke, A. G.; Hong, Y. D.; Kjeld, P. C.; Koide, H.; Lear, G.; Tarasick, D.; Ueno, M.; Wallasch, M.; Baumgardner, D.; Chuang, M. T.; Gillett, R.; Lee, M.; Molloy, S.; Moolla, R.; Wang, T.; Sharps, K.; Adame, J. A.; Ancellet, G.;

Apadula, F.; Artaxo, P.; Barlasina, M. E.; Bogucka, M.; Bonasoni, P.; Chang, L.; Colomb, A.; Cuevas-Agullo, E.; Cupeiro, M.; Degorska, A.; Ding, A. J.; FrHlich, M.; Frolova, M.; Gadhavi, H.; Gheusi, F.; Gilge, S.; Gonzalez, M. Y.; Gros, V.; Hamad, S. H.; Helmig, D.; Henriques, D.; Hermansen, O.; Holla, R.; Hueber, J.; Im, U.; Jaffe, D. A.; Komala, N.; Kubistin, D.; Lam, K. S.; Laurila, T.; Lee, H.; Levy, I.; Mazzoleni, C.; Mazzoleni, L. R.; McClure-Begley, A.; Mohamad, M.; Murovec, M.; Navarro-Comas, M.; Nicodim, F.; Parrish, D.; Read, K. A.; Reid, N.; Ries, N. R. L.; Saxena, P.; Schwab, J. J.; Scorgie, Y.; Senik, I.; Simmonds, P.; Sinha, V.; Skorokhod, A. I.; Spain, G.; Spangl, W.; Spoor, R.; Springston, S. R.; Steer, K.; Steinbacher, M.; Suharguniyawan, E.; Torre, P.; Trickl, T.; Lin, W. L.; Weller, R.; Xu, X. B.; Xue, L. K.; Ma, Z. Q., Tropospheric Ozone Assessment Report: Database and metrics data of global surface ozone observations. Elementa-Science of the Anthropocene 2017, 5, 123.

2. Ostro, B., Outdoor Air Pollution: Assessing the Environmental Burden of Disease at National and Local Levels. World Health Organization Environmental Burden of Disease Series 2004, No. 5, (Geneva).

3. Cohen, A. J.; Brauer, M.; Burnett, R.; Anderson, H. R.; Frostad, J.; Estep, K.; Balakrishnan, K.; Brunekreef, B.; Dandona, L.; Dandona, R.; Feigin, V.; Freedman, G.; Hubbell, B.; Jobling, A.; Kan, H.; Knibbs, L.; Liu, Y.; Martin, R.; Morawska, L.; Pope, C. A.; Shin, H.; Straif, K.; Shaddick, G.; Thomas, M.; van Dingenen, R.; van Donkelaar, A.; Vos, T.; Murray, C. J. L.; Forouzanfar, M. H., Estimates and 25-year trends of the global burden of disease attributable to ambient air pollution: an analysis of data from the Global Burden of Diseases Study 2015. Lancet 2017, 389, (10082), 1907-1918.

4. Jerrett, M.; Burnett, R. T.; Pope, C. A.; Ito, K.; Thurston, G.; Krewski, D.; Shi, Y. L.; Calle, E.; Thun, M., Long-term ozone exposure and mortality. New England Journal of Medicine 2009, 360, (11), 1085-1095.

5. Lelieveld, J.; Evans, J. S.; Fnais, M.; Giannadaki, D.; Pozzer, A., The contribution of outdoor air pollution sources to premature mortality on a global scale. Nature 2015, 525, (7569), 367-371. 